Earth Syst. Sci. Data Discuss., https://doi.org/10.5194/essd-2019-6

Manuscript under review for journal Earth Syst. Sci. Data

Discussion started: 21 January 2019

(c) Author(s) 2019. CC BY 4.0 License.

(c) (1)

1

2

3

4

5

6

7

8

9

10

11

12

13

14

15

16

17

18

19

20

21

22

\section{Data rescue of daily climate station-based observations across Europe}

Joan Ramon Coll ${ }^{1,}$, , Gerard van der Schrier ${ }^{2}$, Enric Aguilar', Dubravka Rasol ${ }^{3}$, Roberto Coscarelli ${ }^{4}$ and Andrés Bishop ${ }^{1}$

${ }^{1}$ Centre for Climate Change (C3), Rovira i Virgili University (URV), Vila-seca - 43480 Spain

${ }^{2}$ Royal Netherlands Meteorological Institute (KNMI), De Bilt - 3730 AE The Netherlands

${ }^{3}$ Croatian Meteorological and Hydrological Service (DHMZ), Zagreb - 10000 Croatia

${ }^{4}$ Consiglio Nazionale della Ricerche - Istituto di Ricerca per la Protezione Idrogeologica (CNR-IRPI), Rende - 87036 Italy

*Corresponding author: joanramon.coll@urv.cat

Gerard van der Schrier: schrier@knmi.nl

Enric Aguilar: enric.aguilar@urv.cat

Dubravka Rasol: rasol@cirus.dhz.hr

Roberto Coscarelli: r.coscarelli@irpi.cnr.it

Andrés Bishop: andres.bishop@gmail.com 
Earth Syst. Sci. Data Discuss., https://doi.org/10.5194/essd-2019-6

Manuscript under review for journal Earth Syst. Sci. Data

Discussion started: 21 January 2019

(c) Author(s) 2019. CC BY 4.0 License.

\section{ABSTRACT}

In the framework of the project "Integrated approach for the development across Europe of user oriented climate indicators for GFCS high-priority sectors: agriculture, disaster risk reduction, energy, health, water and tourism" (INDECIS 2017-2020), around 610K climate station-based observations were rescued over European regions for the main climate variables (maximum and minimum temperature, rainfall, sunshine duration and snow depth) along the $20^{\text {th }}$ century at daily scale. Rescued data will constitute, together with other gathered regional datasets, the INDECIS-Raw-Dataset, which will expand current European data coverage contained in the European Climate Assessment \& Dataset (ECA\&D). An extensive examination of the ECA\&D dataset was conducted to find spatial-temporal data gaps or stations with low percentage of daily data as prior candidates for data recovery in European regions. This exercise led us to focus our efforts on the Central European region and the Balkans. Digitizing was carried out by using a rigorous "key as you see" method, meaning that the digitizers type the values provided by data images, rather than using any coding system. Digitizers carefully cross-checked the typed values against original sources for the $10^{\text {th }}, 20^{\text {th }}$ and $30^{\text {th }}$ day of each month to make sure that no days were skipped or repeated during the digitizing process. Monthly totals and statistical summaries were computed from transcribed data and were compared with monthly totals and summaries provided by data sources to check accuracy as preliminary quality control. The digitizing method and the quality control of the digitizing process applied in this study ensured an accurate data transcription according to the obtained statistics.

The daily dataset rescued in this study across Europe is available at: https://doi.pangaea.de/10.1594/PANGAEA.896957 
Earth Syst. Sci. Data Discuss., https://doi.org/10.5194/essd-2019-6

Manuscript under review for journal Earth Syst. Sci. Data

Discussion started: 21 January 2019

(c) Author(s) 2019. CC BY 4.0 License.

45

46

47

48

49

50

51

52

53

54

55

56

57

58

59

60

61

62

63

64

65

66

67

68

69

70

71

72

73

74

75

76

77

78

79

80

\section{INTRODUCTION}

Meteorological observations in machine readable format are necessary to study observed climate variability and change and for the design of climate products and services, such as regional and global climate models, among others. Nowadays, the lack of climate data for particular regions or for specific historical periods is still affecting negatively climate products increasing the associated uncertainties (Brunet and Jones, 2011). For this reason, data rescue missions are still necessary, especially in developing countries and for pre-mid-20 $0^{\text {th }}$ century data since data stored in log-books or meteorological notebooks are at risk to be lost (WMO, 2016).

Several efforts in the last two decades included data rescue missions in order to enhance the quality and longevity of climate series and achieve a more accurate climate analysis. The European co-funded project entitled "Uncertainties in Ensembles of Regional ReAnalyses" (UERRA 2014-2017) is perhaps one of the most current projects which allocated a great human and economic resources for data rescue purposes. UERRA project allowed to recover around 8.8M of synoptic meteorological observations of the Essential Climate Variables (ECVs) across Europe and some regions of the Mediterranean basin for the period 1877-2012 (Ashcroft et al., 2018). The new high-quality UERRA dataset was submitted to the main global and regional climate data repositories (e.g. Meteorological Archival and Retrieval System - MARS Archive, European Climate Assessment and Dataset -ECA\&D, International Surface Pressure Databank - ISPD -, among others) with the aim to improve model outputs of regional reanalysis and estimate more accurately the associated uncertainties.

On the other hand, the initiative undertaken by the Atmospheric Circulation Reconstructions over the Earth (ACRE, Allan et al., 2011) is in charge to coordinate data rescue activities at global scale. Main tasks are related with major data recovery, imaging and digitization of historical weather observations. The "Mediterranean Data Rescue" (MEDARE) initiative and the "Historical Instrumental Climatological Surface Time Series of The Greater Alpine Region" (HISTALP) are projects focused at regional scale (Auer et al., 2007; Brunet et al., 2014a, 2014b). MEDARE, coordinated by WMO, aims to develop, consolidate and progress climate data and metadata rescue activities across the Greater Mediterranean Region. In the HISTALP project, leaded by the Central Institute of Meteorology and Geodynamics in Austria (ZAMG), a regional database of monthly homogenized temperature, pressure, precipitation, sunshine and cloudiness records was developed from rescued historical climate records. Other initiatives are also carrying out at national scale leaded by National Meteorological and Hydrological Services (NMHSs), such as in Germany (Kaspar et al., 2015).

The European co-funded project INDECIS (Integrated approach for the development across Europe of user oriented climate indicators for GFCS high-priority sectors: agriculture, disaster risk reduction, energy, health, water and tourism), leaded by the Rovira i Virgili University (Tarragona, Spain), will develop user oriented climate indicators across Europe for the GFCS priority sectors (Water, Energy, 
Earth Syst. Sci. Data Discuss., https://doi.org/10.5194/essd-2019-6

Manuscript under review for journal Earth Syst. Sci. Data

Discussion started: 21 January 2019

(c) Author(s) 2019. CC BY 4.0 License.

(c) (1)

81 Health, Agriculture and Food Security, Disaster Risk Reduction) plus Tourism. The project includes 82 efforts in data rescue to expand current ECA\&D dataset across the poorest climate data coverage over 83 some European regions. This paper presents this process. Station-based climate observations were rescued 84 over European sub-regions (mainly Central Europe and Balkans region) for the main climate variables 85 (maximum and minimum temperature, rainfall, sunshine duration and snow depth) along the $20^{\text {th }}$ century 86 at daily scale. Rescued data will constitute, together with other gathered regional datasets, the newly 87 INDECIS-Raw-Dataset, which will expand current European data coverage included in the ECA\&D 88 Dataset. INDECIS-Raw-Dataset will surely further improve the high quality climate products and 89 services across Europe. 
Earth Syst. Sci. Data Discuss., https://doi.org/10.5194/essd-2019-6

Manuscript under review for journal Earth Syst. Sci. Data

Discussion started: 21 January 2019

(c) Author(s) 2019. CC BY 4.0 License.

(c) (i)

91

92

93

94

95

96

97

98

99

100

101

102

103

104

105

106

107

108

109

110

111

112

113

114

115

116

117

118

119

120

121

122

123

124

125

\section{MATERIALS AND METHODS}

This section describes the resources and methodology used in this study to develop data rescue efforts undertaken in the framework of the INDECIS Project. The first step consisted of identifying data gaps in ECA\&D dataset in order to flag the poorest covered regions across Europe. Once identified, the undigitized existing data sources for these particular regions were located and classified. Then, a digitization plan was designed by making an inventory of the priority meteorological stations/periods to be rescued. Climate data was digitized and the metadata for each meteorological station was collected and stored for future quality control and homogenization purposes. Finally, a preliminary assessment of data rescued was undertaken to visualize the added value of DARE efforts by identifying climate extreme events.

\subsection{Inspection of data gaps in ECA\&D dataset}

Data rescue efforts were designed to improve spatial and temporal data coverage of the ECA\&D dataset. The variables of interest were maximum and minimum temperature (TX/TN), rainfall (RR), sunshine duration (SS) and snow depth (SD) at daily scale.

An extensive examination of ECA\&D dataset (http://eca.knmi.nl/) was conducted to find spatial and temporal data gaps across Europe. This preliminary exercise provided us valuable information about which European sub-regions presented lower density of stations (Fig. 1). Regions located in eastern Europe showed the lowest spatial climate data coverage and larger temporal data gaps. In particular, the Balkans region (Croatia, Republic of Serbia, Montenegro, Bosnia and Herzegovina and Republic of Macedonia) was identified as a key region for data rescue missions while other sub-regions from Central Europe (mainly Czech and Slovak Republics), the Mediterranean basin (Italy, Greece and Turkey) also showed a serious lack of climate data coverage. Otherwise, regions with highest density of climate series were focused mainly in Germany, Slovenia, Scandinavia, the Netherlands, Switzerland, France and Great Britain.

\subsection{Identification of undigitized data sources}

Once European sub-regions with lower availability of spatial and temporal climate data coverage were located, the data sources of undigitized records were identified for these particular sub-regions.

The Croatian Meteorological and Hydrological Service (DHMZ located in Zagreb, Croatia) responded positively to our request and provided pdf files containing meteorological records directly scanned from original log-books. 
Earth Syst. Sci. Data Discuss., https://doi.org/10.5194/essd-2019-6

Manuscript under review for journal Earth Syst. Sci. Data

Discussion started: 21 January 2019

(c) Author(s) 2019. CC BY 4.0 License.

\section{(c) (i)}

126 In addition, other undigitized data sources were identified on-line thanks to the WMO MEDARE initiative

127 and the UERRA project through the United States of America's National Oceanic and Atmospheric

128 Administration/National Climatic Data Center (NOAA/NCDC) Climate Data Modernization Project

129 (CDMP: http://docs.lib.noaa.gov/rescue/data rescue home.html) for European eastern regions, the

130 Balkans and the Mediterranean basin (Ashcroft et al., 2018, Brunet et al., 2014a, 2014b). Synoptic station-

131 based observations of atmospheric pressure, air temperature, wind speed and wind direction were already

132 digitized at hourly scale under the UERRA project, but many other meteorological observations remained

133 undigitized at daily scale. The INDECIS project represented a great opportunity to rescue all this amount

134 of non-digitized daily data by using the same data sources already scanned.

135 Table 1 summarizes data sources obtained on-line through CDMP and also provided by the Croatian

136 Meteorological and Hydrological Service depending on each European sub-region and for different

137 periods along the $20^{\text {th }}$ century and the first decade of the $21^{\text {st }}$ century. All of these data sources were also

138 stored in a central server due to heavy size and to avoid data loses.

139 Most of data sources obtained on-line through CDMP were secondary. Unfortunately, secondary data

140 sources are more prominent to keep transcription errors than original data sources. Meteorological

141 observations were handwritten especially in early-20 ${ }^{\text {th }}$ century while they are typed since 1960 s and 70 s.

142 It is also worth to mention that the quality of scans was not always clear and readable and in some cases

143 the meteorological records were hard to read increasing the probability to make transcription errors when

144 digitizing.

145 Once data sources were thoroughly inspected, the digitization plan was designed taking into account the

146 spatial-temporal data gaps previously found in ECA\&D dataset. Thus, an inventory of candidate climate

147 series to be rescued was created prioritizing those stations not included in ECA\&D in order to increase

148 climate data spatial coverage across Europe. Those undigitized periods for the already existing stations at

149 ECA\&D were also digitized to fill temporal data gaps, but not as a priority task.

150 A more detailed information about rescued climate series of the digitization plan can be found in Table

151 2, in which station metadata (e.g. station names, country, WMO code, latitude, longitude and altitude)

152 and type of variables digitised for each station are shown. Rescued periods were variable across time

153 covering the period 1949-2012 for the climate series located in the Balkans region and the period 1917-

1541968 for climate series in Central Europe.

155

156

157

158

159

160

\subsection{Digitizing method}

Before starting with the digitizing procedure, a deep inspection of data sources was necessary to familiarize with the general format, the structure of the data sheets and observations, the source language, the measurement units and other additional notes which can provide valuable climate information 
Earth Syst. Sci. Data Discuss., https://doi.org/10.5194/essd-2019-6

Manuscript under review for journal Earth Syst. Sci. Data

Discussion started: 21 January 2019

(c) Author(s) 2019. CC BY 4.0 License.

161 (metadata). This preliminary inspection of data sources is able to avoid gross digitizing errors derived from some missing sheets for specific months, missing values or missing variables among others. Figures 2, 3 and 4 show examples of the format and structure of scans obtained from various data sources. In particular, Fig. 2, scanned from original log-books provided by the DHMZ, shows daily rainfall and snow depth in Brodanci station (Croatia) due December 1983. It is a handwritten data source in which meteorological records are combined with meteorological symbols and other notes for metadata storage purposes. Figure 3, obtained on-line via CDMP, illustrates the structure of data sources for Central Europe stations. The variables of interest were maximum and minimum temperature, rainfall and snow depth at daily scale for Ceske Budejovice station (Czech Republic) due May 1960 in this case. Mainly typed values are shown with some station identifiers as metadata. Figure 4, also obtained on-line via CDMP, shows the structure and format of data sources for the Balkans region. The variables of interest were typed maximum and minimum temperature, rainfall, snow depth and sunshine duration at daily scale for Sarajevo station (Bosnia and Herzegovina) due July 1959.

Once all scans of data sources were thoroughly inspected, the digitizing process was set up. The digitizing method used in this study consisted of applying a rigorous "key as you see" approach, meaning that each digitizer was in charge to transcribe meteorological observations as were handwritten/typed in data sources, without using any system code, following the recommendations given by WMO (2016). Digitization was done over a spreadsheet designed for data insertion by following the format of each variable in the hard copies. Half screen of the computer was used to read data from data sources and the other half for typing meteorological records in the spreadsheet (Fig. 5). The digitizers used real-time quality control strategies to minimize the instruction of erroneous values. They cross-checked the digitized values against data sources every $10^{\text {th }}, 20^{\text {th }}$ and $30^{\text {th }}$ for each month to check accuracy (to avoid repeated or skipped values). Also compared monthly totals and averages of digitized values with the monthly summaries provided in the hard copies, when they were available. Digitizing errors were reported in a specific template (Fig. 6) while corrections were applied by using a copy of the first series to preserve data traceability. The structure of the template used to document the preliminary quality control process can be found in Fig. 6. This template informs us about some basic station metadata (e.g. country, name of station and $\mathrm{WMO} /$ local code as identifier), the exact date and variable when a digitizing error was produced (year, month, day and variable), the original value (erroneous) and the replacement value (the correct one), the type of error (e.g. transcription error, source error, typing error...), the procedure applied (corrected or set to missing) and any other comments for a better understanding of the type of error or the final decision taken (e.g. hard to read, no sheet in data source, no station,...). 
Earth Syst. Sci. Data Discuss., https://doi.org/10.5194/essd-2019-6

Manuscript under review for journal Earth Syst. Sci. Data

Discussion started: 21 January 2019

(c) Author(s) 2019. CC BY 4.0 License.

197

198

199

200

201

202

203

204

205

206

207

208

209

210

211

212

213

214

215

216

217

218

219

220

221

222

223

224

225

226

227

228

229

230

231

232

\subsection{Metadata collection}

Data gaps and potential unexpected variations in data sources were also recorded in a metadata spreadsheet following the recommendations outlined by Aguilar et al. (2003).

Table 3 shows an example of a metadata template used for collecting additional notes for each station divided in six basic sections.

The first section was designed to acquire metadata from data sources including the title of the source, the period covered, the hosting, link (if any) to be found on-line and the variables. The second section was related to station identifiers (stations name, country, WMO code, latitude, longitude and altitude (m)) while the third one contained valuable information about variables (variable name, units, period and observing times). Section 4 was used to inform about special codes (e.g. code -99.9 for missing values, or code -3 for rainfall $<0.1 \mathrm{~mm}$ among others). Section 5 was used to describe the dates or periods with missing values in data sources indicating the incident (e.g. no data for that station, hard to read values due to poor quality of scans, or no sheet for any reason). Finally, section 6 was used to identify changes in meteorological stations that could have an impact on observations, such as re-location of meteorological station, instrumental changes, among others. This particular information is useful to understand unexpected data behaviors or abrupt shifts for quality control and homogenization purposes.

\subsection{Computation of climate extreme indices}

Six of the 26 core climate extreme indices defined by the Expert Team on Climate Change Detection and Indices (ETCCDI) (Peterson et al., 2001) plus two specific drought indices were selected to be computed over Belgrade time-series for the whole period 1920-2017 to highlight, as example, the importance of DARE efforts in terms of identifying climate extreme events. ETCCDI indices are based on daily temperature values or daily precipitation amount. Some of them use fixed thresholds based on absolute values meanwhile others use percentiles of the relevant data series to make comparisons between different locations. The list of the 26 core ETCCDI indices and their definitions are available at: http://etccdi.pacificclimate.org/list_27_indices.shtml. For this preliminary assessment six ETCCDI indices were selected and computed at annual time scale to identify cold and dry years: TX10p, TN10p, FD, CSDI, PRCPTOT and CDD. TX10p and TN10p indices shows the percentage of days when TX and TN are lower than $10^{\text {th }}$ percentile (cold days and cold nights) computed for the base-period 1961-1990. FD index reports the number of frost days $\left(\mathrm{TN}<0^{\circ} \mathrm{C}\right)$ per year meanwhile CSDI refers to the cold spell duration index identifying the annual account of days with at least six consecutive days when $\mathrm{TN}<10^{\text {th }}$ percentile. PRCPTOT index is the annual total precipitation in wet days and the CDD refers to the maximum number of consecutive days with $\mathrm{RR}<1 \mathrm{~mm}$. 
Earth Syst. Sci. Data Discuss., https://doi.org/10.5194/essd-2019-6

Manuscript under review for journal Earth Syst. Sci. Data

Discussion started: 21 January 2019

(c) Author(s) 2019. CC BY 4.0 License.

(c) (i)

233 Two additional specific drought indices were also computed to identify major droughts in Belgrade series 234 for the period 1920-2017. The most widely used Standardized Precipitation Index (SPI) (McKee et al., 235 1993) driven only by precipitation, and the Standardized Precipitation-Evapotranspiration Index (SPEI)

236 (Vicente-Serrano et al., 2010), based on the difference between the precipitation and the reference 237 evapotranspiration. Both drought indices were computed at the 6-month time scale to identify 238 accumulated dry conditions across time. Reference evapotranspiration were calculated by using the 239 Hargreaves algorithm (Hargreaves and Samani, 1985), which needs maximum and minimum temperature 240 together with extraterrestrial solar radiation (performed from latitude and the day of the year). The 241 calibration period was the longest period available for the Belgrade series (1920-2017) to compute both 242 SPI and SPEI indices following the recommendations outlined by Beguería et al., (2014) and Trenberth 243 et al., (2014). 
Earth Syst. Sci. Data Discuss., https://doi.org/10.5194/essd-2019-6

Manuscript under review for journal Earth Syst. Sci. Data

Discussion started: 21 January 2019

(c) Author(s) 2019. CC BY 4.0 License.

\section{(c) (i)}

\section{RESULTS}

This section describes the results derived from data rescue activities under the INDECIS project. After applying the digitizing method detailed in section 2.3, the results in terms of amount of digitized values and their spatial-temporal distribution are explained in this section. Results derived from the applied quality control of the digitizing procedure are described and a preliminary assessment of the rescued data is also carried out.

\subsection{Spatial-temporal distribution of rescued observations}

A total of $610 \mathrm{~K}$ daily observations were rescued in the INDECIS project for maximum and minimum temperature (in ${ }^{\circ} \mathrm{C}$ ), rainfall (in mm), sunshine duration (in hours) and snow depth (in $\mathrm{cm}$ ) across Central Europe and the Balkans region along really variable periods along the $20^{\text {th }}$ century (Coll et al., 2019). Figure 7 shows the spatial distribution of the 25 rescued climate series located in 7 European countries: 11 climate series in Czech Republic, 5 in Slovak Republic, 3 in Republic of Serbia, two in Bosnia and Herzegovina, two more climate series in Republic of Macedonia, one in Croatia and the last one in Montenegro (see also Table 4). The 25 climate series will be included in the INDECIS-Raw-Dataset (together with gathered series obtained from other regionals datasets and not described in this study). Table 4 shows a summary of number of rescued stations and total amount of digitised values for each country. Rescued variables and periods are also described. Maximum and minimum temperature, rainfall and snow depth were the rescued variables in Czech and Slovak Republic, while sunshine duration was also included in the Balkans region (except in Croatia, where only rainfall and snow depth were digitized). Digitizing periods were extended from 1917 to 1968 in Czech Republic and 1919-1968 in Slovak Republic. In the Balkans region, digitizing periods focused on 1920-2012 in the Republic of Serbia, 19491960 in Bosnia and Herzegovina, 1949-1984 in both Montenegro and Republic of Macedonia and, finally, the period 1930-1990 was digitized in Croatia. Nevertheless, these common periods were really variable among stations. More details about particular periods for each station can be found recovering Table 2. Figures 8 and 9 show the total amount of digitized values for each country and for each variable, respectively. The largest amount of digitized values corresponds to stations in the Czech Republic, which nearly $250 \mathrm{~K}$ values were rescued. Follow Slovak Republic with greater than $110 \mathrm{~K}$ values, Republic of Serbia with more than $85 \mathrm{~K}$ values and Montenegro with nearly 65K values. Finally, the total amount of digitized observations was lower in Croatia, Republic of Macedonia and in Bosnia and Herzegovina due to the short length of digitizing periods, multiple data gaps and less variables to be digitized (e.g. in Croatia).

A total of nearly $260 \mathrm{~K}$ values were rescued in both maximum (TX) and minimum (TN) temperature (Fig. 9) meanwhile close to $160 \mathrm{~K}$ values and greater than $150 \mathrm{~K}$ values were rescued related to rainfall (RR) 
Earth Syst. Sci. Data Discuss., https://doi.org/10.5194/essd-2019-6

Manuscript under review for journal Earth Syst. Sci. Data

Discussion started: 21 January 2019

(c) Author(s) 2019. CC BY 4.0 License.

\section{(c) (i)}

282 and snow depth (SD), respectively. In less proportion, greater than $40 \mathrm{~K}$ values were rescued related to 283 sunshine duration (SS). The main differences among the amount of digitized values for each variable 284 depended basically on the availability (or not) of such variables in the data sources.

285

286

287

288

289

290

291

292

293

294

295

296

297

298

299

300

301

302

303

304

305

306

307

308

309

310

311

312

313

314

315

316

317

\subsection{Quality Control}

The quality control of the digitizing process was applied to all climate series rescued in the INDECIS Project. Monthly totals and sums provided by data sources (in most of the cases) were accurately crosschecked with monthly totals and sums computed from digitized data. Results demonstrated that the errors occurred during the digitizing process represented only the $0,6 \%$ of the total amount of digitized values, which highlights the accuracy and high standards of the process and ensures the transmission of readyto-use data series. Most of errors occurred due to hard to read records (around 76\% of errors; Fig. 10). The main cause was the low quality of particular sheets in the scanned data sources. The second cause of errors was variable confusion or, what means the same, column confusion in data sources (around $17 \%$ of errors). In those cases, the digitizer did not realize that they were typing the wrong variable. This could be solved by using templates that exactly match data sources with spreadsheets. Finally, the $7 \%$ of errors were typing errors produced during the digitizing process (e.g. type $104,5^{\circ} \mathrm{C}$ instead $10,5^{\circ} \mathrm{C}$ ). All errors found in the preliminary quality control of the digitizing process were successfully corrected or were set to missing in the cases that a new value could not be offered.

The 25 new climate series will be incorporated to the INDECIS-Raw-Dataset and submitted for addition into the ECA\&D Dataset. Thus, the spatial-temporal climate coverage will surely improve in Central Europe and in the Balkans region. More exhaustive quality control routines are strongly recommended to find non-systematic errors together with the application of some homogenization tests to ensure the high quality of the new dataset to be used for future climate analysis.

\subsection{Preliminary assessment of rescued data}

In this section, we intend to visualize the effects of data rescue and explain the impact of data rescue over climate series. No need to say that the solid climatological conclusions cannot be drawn from them, as the data has not been assessed for homogeneity, but the benefits of data rescue are highlighted.

For example, Fig. 11 shows the evolution of daily maximum (TX) minimum (TN) temperature and precipitation (RR) at Belgrade station (Republic of Serbia) for the period 1920-2017. Data rescue efforts allowed to extend 15 years back to 1936 creating a long-term time series of almost 100 years of records. Focusing on the rescued period (blue line), extreme cold temperatures can be identified in 1922, 1935, but especially in 1929. In particular, February 1929 was extremely cold in Belgrade reaching temperatures on record in both maximum and minimum temperature for the whole time series. Minimum temperature 
Earth Syst. Sci. Data Discuss., https://doi.org/10.5194/essd-2019-6

Manuscript under review for journal Earth Syst. Sci. Data

Discussion started: 21 January 2019

(c) Author(s) 2019. CC BY 4.0 License.

\section{(c) (i)}

318 reached $-25,5^{\circ} \mathrm{C}$ and maximum temperature did not exceed $-18,5^{\circ} \mathrm{C}$ in a particular day. The evolution of 319 precipitation (Fig. 11) for the rescued period 1920-1935 shows dry conditions in 1920-1921, 1923 and 3201928 meanwhile wet conditions were predominant in 1924-1927 and 1931-1933.

321 Data rescue efforts extend climatological analysis to the past. Even though the Belgrade series shown in 322 Fig. 11 are neither quality controlled and homogenized, the calculation of some ETCCDI indices 323 (Peterson et al., 2001) plus two specific drought indices (SPI and SPEI) suggests some climate features 324 that could not be studied before this DARE effort. For example, in the cold 1929 year (Fig. 12) or the dry

event experienced in 1920-1921 in Belgrade (Fig. 13).

According to these indices (Fig. 12) 1929 is identified as a cold year, with a high percentage (> 20\%) of cold days (TX10p) and nights (TN10p), over 100 frost days (FD) and 55 days singled out as part of a cold spell (CSDI). The mentioned cold spell occurred in February 1929 and was general over most of Europe being the coldest month on record in Poland (Sirocko et al., 2012). The Rhine river was frozen in Germany taking into account that only occurred it six times during the $20^{\text {th }}$ century and the canals were also frozen in Venice according to the Meteorological Magazine published for the UK Meteorological Office in March 1929.

Figure 13 shows the PRCPTOT, SPI 6-month, SPEI 6-month and CDD indices computed over the Belgrade rescued time series for the period 1920-2017. These specific extreme indices were selected to identify the dry event occurred in 1920-1921. Annual precipitation amount (PRCPTOT index) was low in 1920 compared with other years of the time series $(<500 \mathrm{~mm})$ and the consecutive dry days index (CDD) shows that there was a period with more than 40 days with precipitation less than $1 \mathrm{~mm}$. The computation of additional drought indices such as SPI 6-month and SPEI 6-month allowed to identify the driest event of the whole Belgrade series reaching maximum severity in 1921. This drought event not only affected a particular European region, but most of European countries suffered severe dry conditions during several months between years 1920 and 1923 (Hanel et al., 2018). In fact, West Europe was in serious drought during 1920 and 1921, which was reported by the “Townsville Daily Bulletin” in July 1921. High pressure systems from the Azores remained stuck for almost the entire year, leading to clear skies and dire shortages of rain. Most rivers in France were below the lowest records in 50 years, the mountain torrents in Switzerland were not a third of their usual volume and the dry sequence lasted 86 consecutive days for most of Britain.

\section{DATA AVAILABILITY}

The daily dataset rescued in this study across Europe is available at the PANGAEA repository: https://doi.pangaea.de/10.1594/PANGAEA.896957 
Earth Syst. Sci. Data Discuss., https://doi.org/10.5194/essd-2019-6

Manuscript under review for journal Earth Syst. Sci. Data

Discussion started: 21 January 2019

(c) Author(s) 2019. CC BY 4.0 License.

\section{SUMMARY AND CONCLUSIONS}

355

356

357

358

359

360

361

362

363

364

365

366

367

368

369

370

371

372

373

374

375

376

377

378

379

380

381

382

383

384

385

386

387

388

389
In the framework of the INDECIS Project, some human and economic resources were allocated for data rescue activities across Europe in order to enhance the quality in the already existing climate products and services. This study deeply describes all the process carried out: from the identification of data gaps in ECA\&D dataset and the inspection of undigitized data sources to the digitizing process together with the accurate documentation of data and metadata, including also the corrections derived from digitizing errors.

The process of identifying data gaps, the inspection of data sources to be rescued and the preparation of aforementioned data sources was actually a time consuming task (Bröninnmann, 2006). In particular, several hours of work and human resources were needed during the manual-keying digitizing process. For this reason, it was crucial to design and implement an effective and reliable digitizing method to obtain the final high-quality climate dataset avoiding extra-costs.

Some recommendations are available to guide experts involved in data rescue projects or initiatives. In this line, Bröninnmann (2006) designed a digitizing guide for climate data describing the use of technologies based on optical character recognition (OCR) technologies or based on speech recognition techniques to be faster in the digitizing procedure. Nevertheless, the study demonstrated that the manualkeying digitizing process was the most efficient method in terms of agility, reduction of transcription errors and post-process time consuming. The World Meteorological Organization supported this statement (WMO, 2016) recommending the use of OCRs only in a certain data sources, since human eye is still more effective transcribing handwritten data sources.

Nowadays, the most effective method of digitization is double or triple-keying data by using templates that match with format of original data sources (WMO, 2016). Despite this, the final economic cost is remarkably higher and most of projects cannot assume this extra cost. Simple manual-keying with an effective quality control during and at the end of the digitization process resulted the better balance between costs and data quality of rescued datasets knowing that some issues to solve already exist (Ashcroft et al., 2018).

In summary, a total of 25 climate series (610K daily observations) were rescued in this study for 7 countries of the Central Europe and the Balkans region along the $20^{\text {th }}$ century by using the manual-keying digitizing method together with a preliminary quality control of the digitizing procedure (Coll et al., 2019). Climate variables of interest were maximum and minimum temperature, rainfall, sunshine duration and snow depth. The aforementioned rescued climate series will be included in the newly INDECIS-RawDataset, which will be automatically ingested by the ECA\&D Dataset to fill the spatial-temporal data gaps previously identified across Europe.

Rescued dataset will be submitted to more rigorous quality control routines to detect non-systematic errors (Aguilar et al., 2003) together with some homogenisation tests (Venema et al., 2012) to ensure a high- 
Earth Syst. Sci. Data Discuss., https://doi.org/10.5194/essd-2019-6

Manuscript under review for journal Earth Syst. Sci. Data

Discussion started: 21 January 2019

(c) Author(s) 2019. CC BY 4.0 License.

(c) (1)

390 quality and homogeneous data to be used by the international research community to design and 391 implement new climate products and services.

392 Future European climate analysis will be benefited of DARE efforts undertaken in this study such as 393 increasing the reliability of long-term climate trends or identifying historical climate extremes among 394 others.

395

396

397

398

399

400

401

402

403

404

405

406

407

408

409

410

411

412

413

414

415

416

\section{AUTHOR CONTRIBUTION}

Joan Ramon Coll: Searcher of undigitised data sources, developer of data inventories, in charge of the manual digitization process (typing), extreme indices computation and analysis and manuscript preparation.

Gerard van der Schrier: Everything related to ECA\&D management: Inventory of digitised stations/periods, provider of digitised data and ECA\&D data gaps inspection).

Enric Aguilar: Designer of the digitization plan, supervisor of the digitization process and quality control and paper structure designer.

Dubravka Rasol: Scanning and providing undigitized data for the Balkan region.

Roberto Coscarelli: Supervisor of the extreme indices analysis and detection of extreme events and also paper reviewer.

Andrés Bishop: In charge of quality control process of digitization.

\section{ACKNOWLEDGEMENTS}

The Project INDECIS is part of ERA4CS, an ERA-NET initiated by JPI Climate, and funded by FORMAS (SE), DLR (DE), BMWFW (AT), IFD (DK), MINECO (ES), ANR (FR) with co-funding by the European Union (Grant 690462).

The authors declare that they have no conflict of interest. 
Earth Syst. Sci. Data Discuss., https://doi.org/10.5194/essd-2019-6

Manuscript under review for journal Earth Syst. Sci. Data

Discussion started: 21 January 2019

(c) Author(s) 2019. CC BY 4.0 License.

417

418

419

420

421

422

423

424

425

426

427

428

429

430

431

432

433

434

435

436

437

438

439

440

441

442

443

444

445

446

447

448

449

450

451

\section{REFERENCES}

Aguilar, E., Auer, I., Brunet, M., Peterson, T. C. and Wieringa, J. (2003). Guidelines on Climate Metadata and Homogenization, World Meteorological Organisation, (1186), 55.

Allan, R., Brohan, P., Compo, G. P., Stone, R., Luterbacher, J., Brönnimann, S., Allan, R., Brohan, P., Compo, G. P., Stone, R., Luterbacher, J. and Brönnimann, S. (2011). The International Atmospheric Circulation Reconstructions over the Earth (ACRE) Initiative, Bulletin of American Meteorological Society, 92(11), 1421-1425, doi:10.1175/2011BAMS3218.1.

Ashcroft L., Coll J.R., Gilabert A., Domonkos P., Aguilar E., Sigró J., Castellà M., Unden P., Harris I., Jones P., Brunet M. (2018). A rescued dataset of sub-daily meteorological observations for Europe and the Mediterranean region, 1877-2012. Earth System Science Data, 10, 1613-1635, https://doi.org/10.5194/essd-10-1613-2018, 2018.

Auer, I., Böhm, R., Jurkovic, A., Lipa, W., Orlik, A., Potzmann, R., Schöner, W., Ungersböck, M., Matulla, C., Briffa, K., Jones, P., Efthymiadis, D., Brunetti, M., Nanni, T., Maugeri, M., Mercalli, L., Mestre, O., Moisselin, J.-M., Begert, M., Müller-Westermeier, G., Kveton, V., Bochnicek, O., Stastny, P., Lapin, M., Szalai, S., Szentimrey, T., Cegnar, T., Dolinar, M., Gajic-Capka, M., Zaninovic, K., Majstorovic, Z. and Nieplova, E. (2007). HISTALP—historical instrumental climatological surface time series of the Greater Alpine Region, International Journal of Climatology, 27(1), 17-46, doi:10.1002/joc.1377.

Beguería S, Vicente-Serrano SM, Reig F, Latorre B (2014) Standardized precipitation evapotranspiration index (SPEI) revisited: parameter fitting, evapotranspiration models, tools, datasets and drought monitoring. Int J Climatol 34:3001-3023. doi: 10.1002/joc.3887.

Brönnimann, S., Annis, J., Dann, W., Ewen, T., Grant, A. N., Griesser, T., Krähenmann, S., Mohr, C., Scherer, M. and Vogler, C. (2006). A guide for digitising manuscript climate data, Climate of the Past, 2(3), 191-207, doi:10.5194/cpd-2-191-2006.

Brunet, M. and Jones, P. (2011). Data rescue initiatives: bringing historical climate data into the 21st century, Climate Research, 47(1), 29-40, doi:10.3354/cr00960. 
Earth Syst. Sci. Data Discuss., https://doi.org/10.5194/essd-2019-6

Manuscript under review for journal Earth Syst. Sci. Data

Discussion started: 21 January 2019

(c) Author(s) 2019. CC BY 4.0 License.

452 Brunet, M., Gilabert, A., Jones, P. and Efthymiadis, D. (2014a). A historical surface climate dataset from 453 station observations in Mediterranean North Africa and Middle East areas. Geoscience Data Journal, 1(2), 454 121-128, doi:10.1002/gdj3.12.

455

456

457

458

459

460

461

462

463

464

465

466

467

468

469

470

471

472

473

474

475

476

477

478

479

480

481 Sirocko F., Brunck H. and Pfahl S. (2012). Solar influence on winter severity in Cetral Europe.

482 Geophysical research Letters, Vol. 39, L16704, doi: 10.1029/2012GL052412.

483 Trenberth KE, Dai A, van der Schrier G, Jones PD, Barichivich J, Briffa KR, Sheffield J (2014) Global 484

Brunet, M., Jones, P. D., Jourdain, S., Efthymiadis, D., Kerrouche, M. and Boroneant, C. (2014b). Data sources for rescuing the rich heritage of Mediterranean historical surface climate data, Geoscience Data Journal, 1(1), 61-73, doi:10.1002/gdj3.4.

Coll, J.R., van der Schrier, G., Aguilar, E., Rasol, D., Coscarelli, R., Bishop, A. (2019): Daily rescued meteorological observations across Europe (1917-1990). PANGAEA, https://doi.pangaea.de/10.1594/PANGAEA.896957.

Hanel M., Rakovec O., Markonis Y., Máca P., Samaniego L., Kysely J and Kumar R. (2018). Revisiting the recent European droughts froma long-term perspective. Nature Scientific Reports 8, Article number: 9499 (2018).

Hargreaves, G.L., Samani, Z.A. 1985. Reference cop evapotranspiration from temperature. Applied Engineering and Agriculture 1, 96-99.

Kaspar, F., Tinz, B., Mächel, H. and Gates, L. (2015). Data rescue of national and international meteorological observations at Deutscher Wetterdienst, Advances on Science Research, 12, 57-61, doi:10.5194/asr-12-57-2015.

Kendall MG (1970) Rank Correlation Methods (4th ed). Griffin and Co. Ltd

McKee TBN, Doesken J, and Kleist J, (1993) The relationship of drought frequency and duration to time scales. Eight Conf. On Applied Climatology. Anaheim, CA, Amer. Meteor. Soc. 179-184

Peterson, T.C., and Coauthors. (2001). Report on the Activities of the Working Group on Climate Change Detection and Related Rapporteurs 1998-2001. WMO, Rep. WCDMP-47, WMO-TD 1071, Geneve, Switzerland, 143pp.

warming and changes in drought. Nat Clim Chang 4:17-22. doi: 10.1038/nclimate2067 
Earth Syst. Sci. Data Discuss., https://doi.org/10.5194/essd-2019-6

Manuscript under review for journal Earth Syst. Sci. Data

Discussion started: 21 January 2019

(c) Author(s) 2019. CC BY 4.0 License.

(c) (1)

485 Venema, V. K. C., Mestre, O., Aguilar, E., Auer, I., Guijarro, J. A., Domonkos, P., Vertacnik, G., 486 Szentimrey, T., Stepanek, P., Zahradnicek, P., Viarre, J., Müller-Westermeier, G., Lakatos, M., Williams, 487 C. N., Menne, M. J., Lindau, R., Rasol, D., Rustemeier, E., Kolokythas, K., Marinova, T., Andresen, L., 488 Acquaotta, F., Fratianni, S., Cheval, S., Klancar, M., Brunetti, M., Gruber, C., Prohom Duran, M., Likso, 489 T., Esteban, P. and Brandsma, T. (2012). Benchmarking homogenization algorithms for monthly data, 490 Climate of the Past, 8(1), 89-115, doi:10.5194/cp-8-89-2012.

491

492

493

Vicente-Serrano SM, Beguería S, López-Moreno JI (2010) A multi-scalar drought index sensitive to global warming: the standardized precipitation evapotranspiration index. J Clim 23:1696-1718. doi: 10.1175/2009JCLI2909.1

Wang XL, Swail VR (2001) Changes of extreme wave height in northern hemisphere oceans and related 498 atmospheric circulation regimes. Journal of Climate Volume 14:12-45

500

World Meteorological Organization (2016). Guidelines on Best Practices for Climate Data Rescue 2016. 
Earth Syst. Sci. Data Discuss., https://doi.org/10.5194/essd-2019-6

Manuscript under review for journal Earth Syst. Sci. Data

Discussion started: 21 January 2019

(c) Author(s) 2019. CC BY 4.0 License.

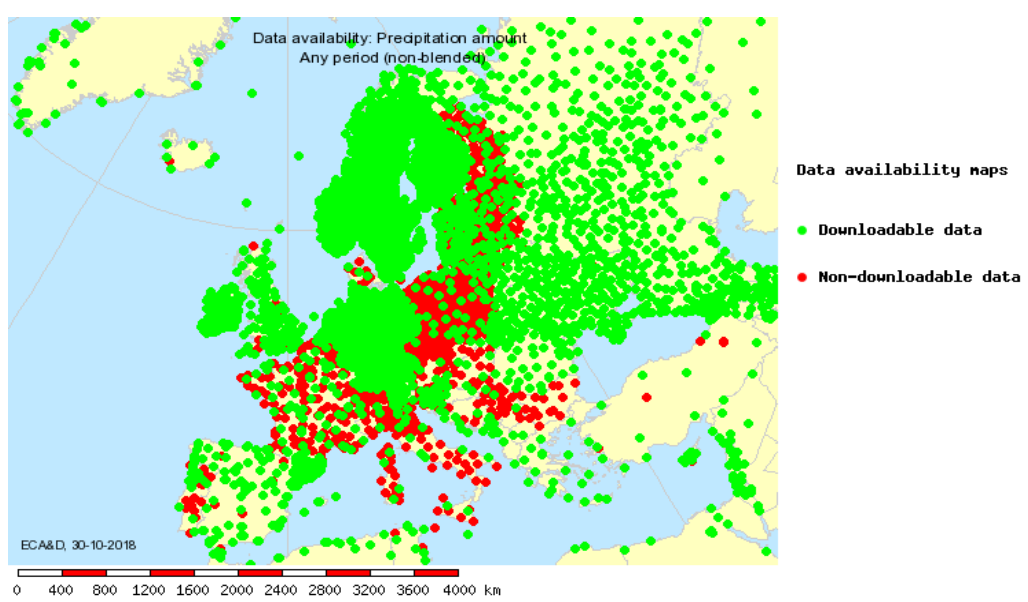

Fig. 1: Spatial distribution of meteorological stations in ECA\&D (precipitation as example) across Europe in 2018. Downloadable stations are in green and non-downloadable stations in red. 
Earth Syst. Sci. Data Discuss., https://doi.org/10.5194/essd-2019-6

Manuscript under review for journal Earth Syst. Sci. Data

Discussion started: 21 January 2019

(c) Author(s) 2019. CC BY 4.0 License.

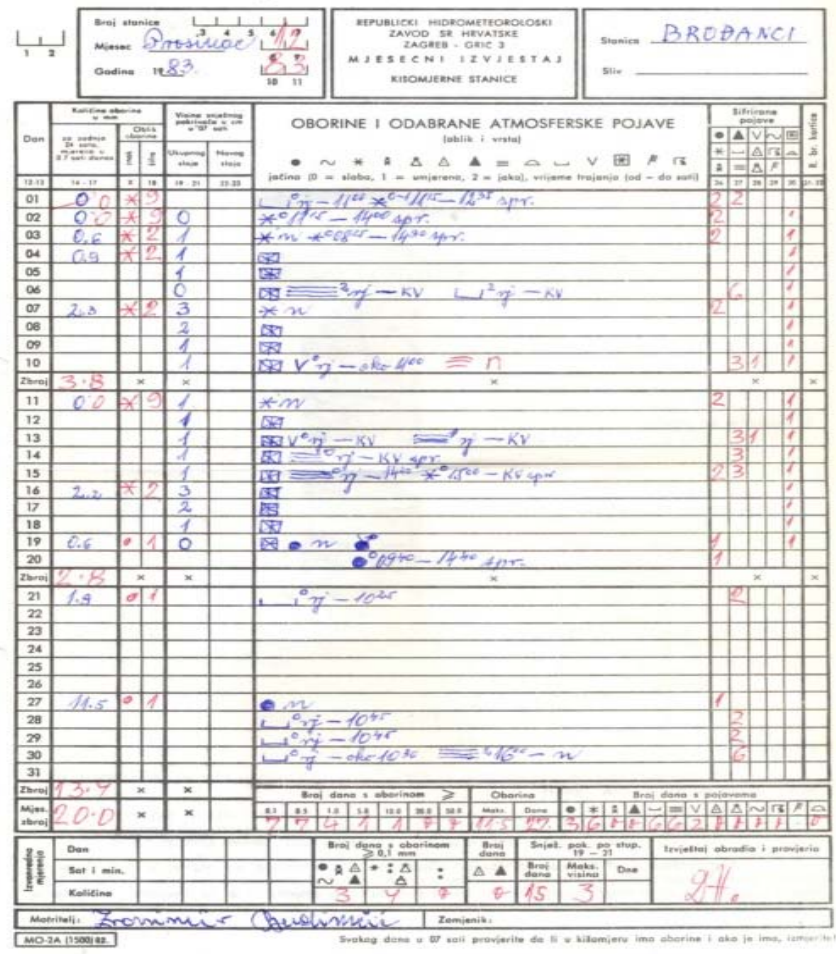

Fig. 2: Structure of original log-books (scans) provided by the Croatian Meteorological Service; Brodanci station (Croatia), December 1983. 
Earth Syst. Sci. Data Discuss., https://doi.org/10.5194/essd-2019-6

Manuscript under review for journal Earth Syst. Sci. Data

Discussion started: 21 January 2019

(c) Author(s) 2019. CC BY 4.0 License.

509

510

511

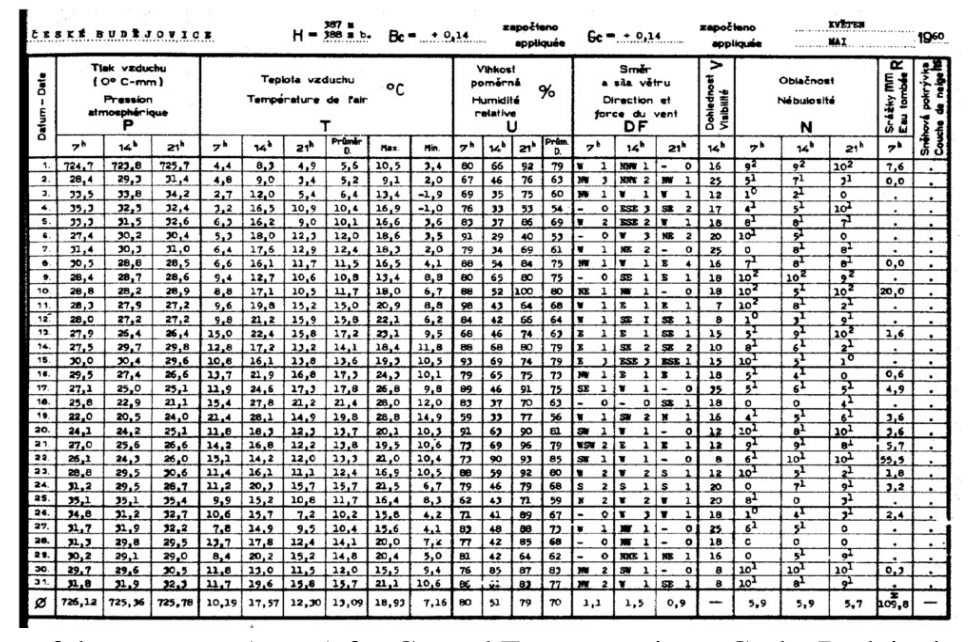

Fig. 3: Structure of data sources (scans) for Central Europe stations: Ceske Budejovice station (Czech Republic), May 1960.

JUL 1959

\section{SARAJEVO}

Br. st. 272

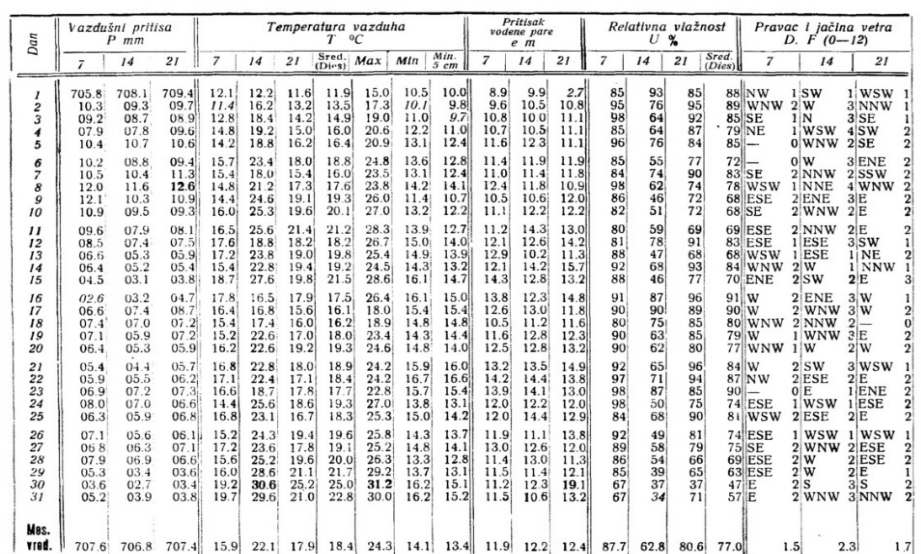

Fig. 4: Structure of data sources (scans) for the Balkans region: Sarajevo station (Bosnia \& Herzegovina), July 1959. 
Earth Syst. Sci. Data Discuss., https://doi.org/10.5194/essd-2019-6

Manuscript under review for journal Earth Syst. Sci. Data

Discussion started: 21 January 2019

(c) Author(s) 2019. CC BY 4.0 License.

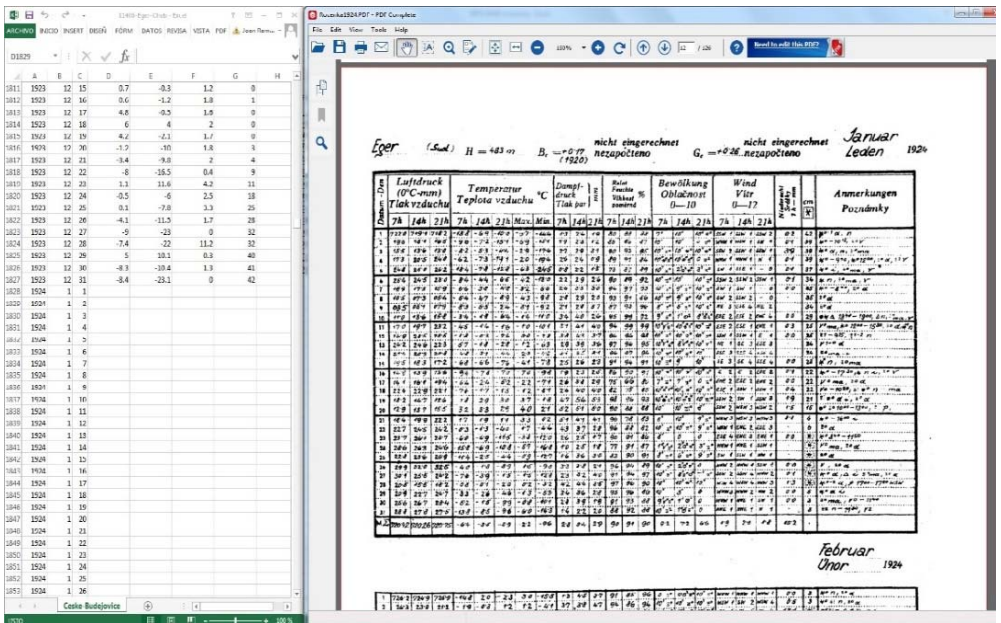

Fig. 5: Example of the manual-keying data transcription method used during the digitization process; from scanned data sources (right) to digital spreadsheets (left).

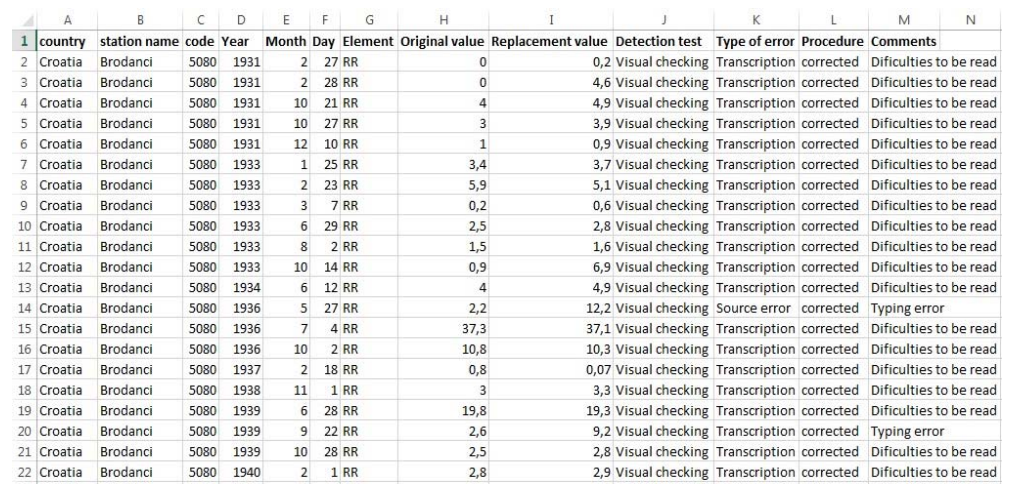

Fig. 6: Template used to report the quality control of the digitization process. 
Earth Syst. Sci. Data Discuss., https://doi.org/10.5194/essd-2019-6

Manuscript under review for journal Earth Syst. Sci. Data

Discussion started: 21 January 2019

(c) Author(s) 2019. CC BY 4.0 License.
523

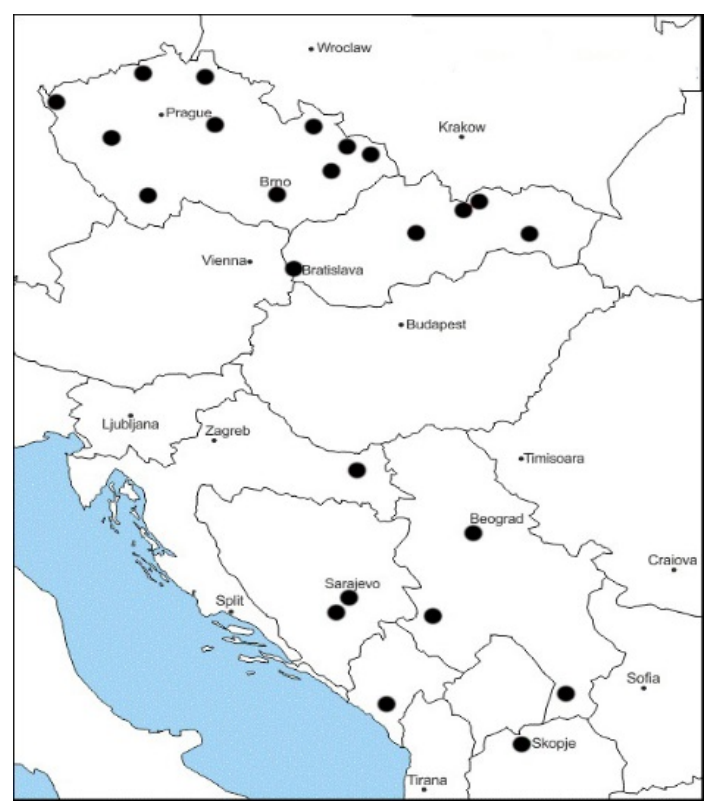

Fig. 7: Spatial distribution of rescued stations

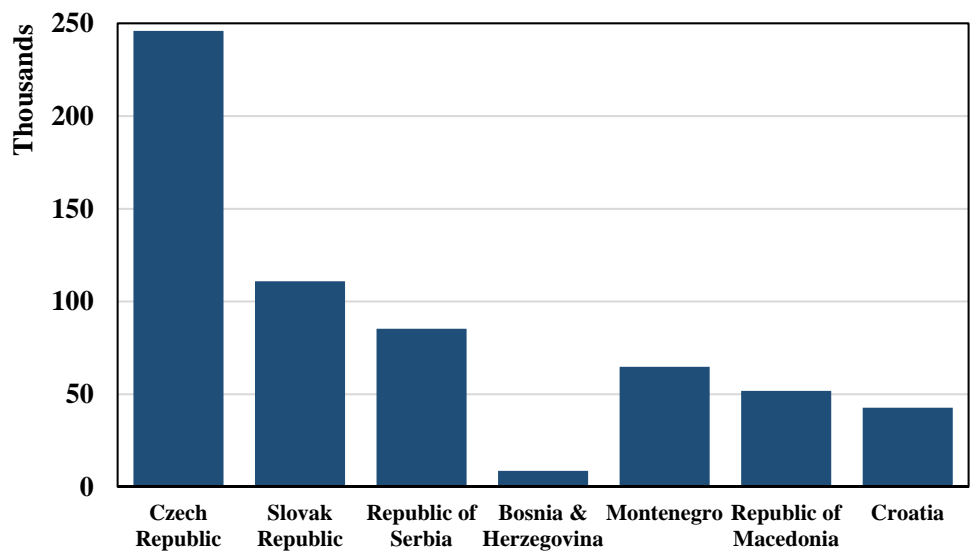

Fig. 8: Total amount of digitized values (in thousands) by countries 
Earth Syst. Sci. Data Discuss., https://doi.org/10.5194/essd-2019-6

Manuscript under review for journal Earth Syst. Sci. Data

Discussion started: 21 January 2019

(c) Author(s) 2019. CC BY 4.0 License.

(c) (i)

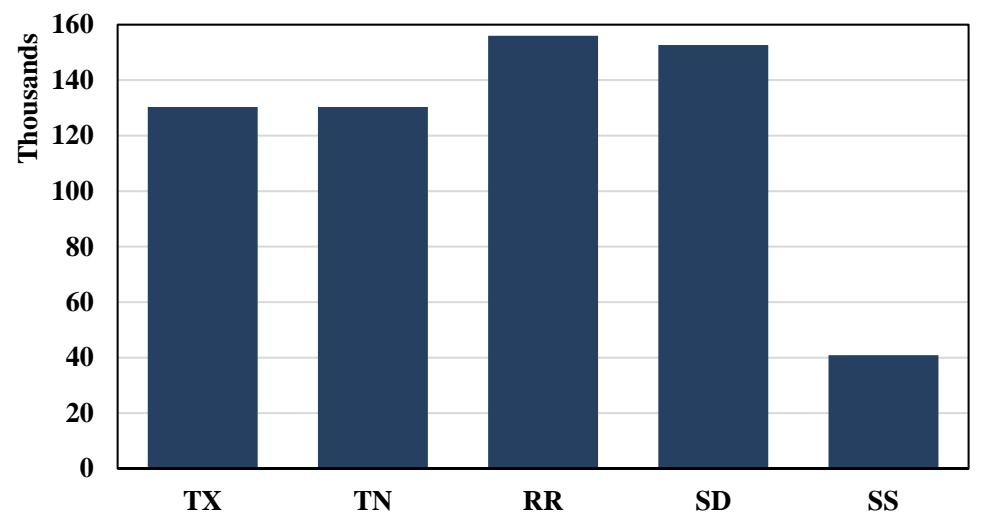

Fig. 9: Total amount of digitized values (in thousands) by variables

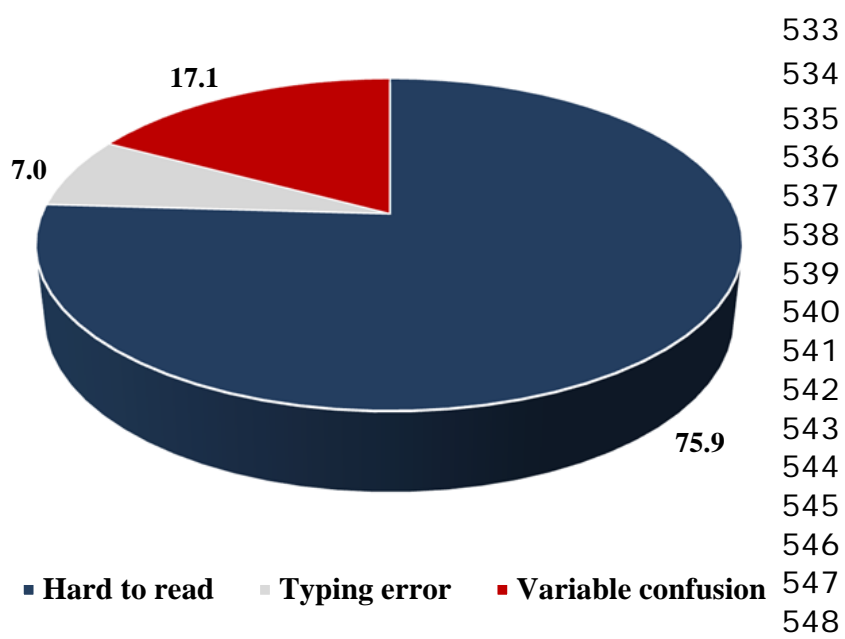

Figure 10: Percentage of type of errors found after the quality control of the digitizing procedure. 
Earth Syst. Sci. Data Discuss., https://doi.org/10.5194/essd-2019-6

Manuscript under review for journal Earth Syst. Sci. Data

Discussion started: 21 January 2019

(c) Author(s) 2019. CC BY 4.0 License.
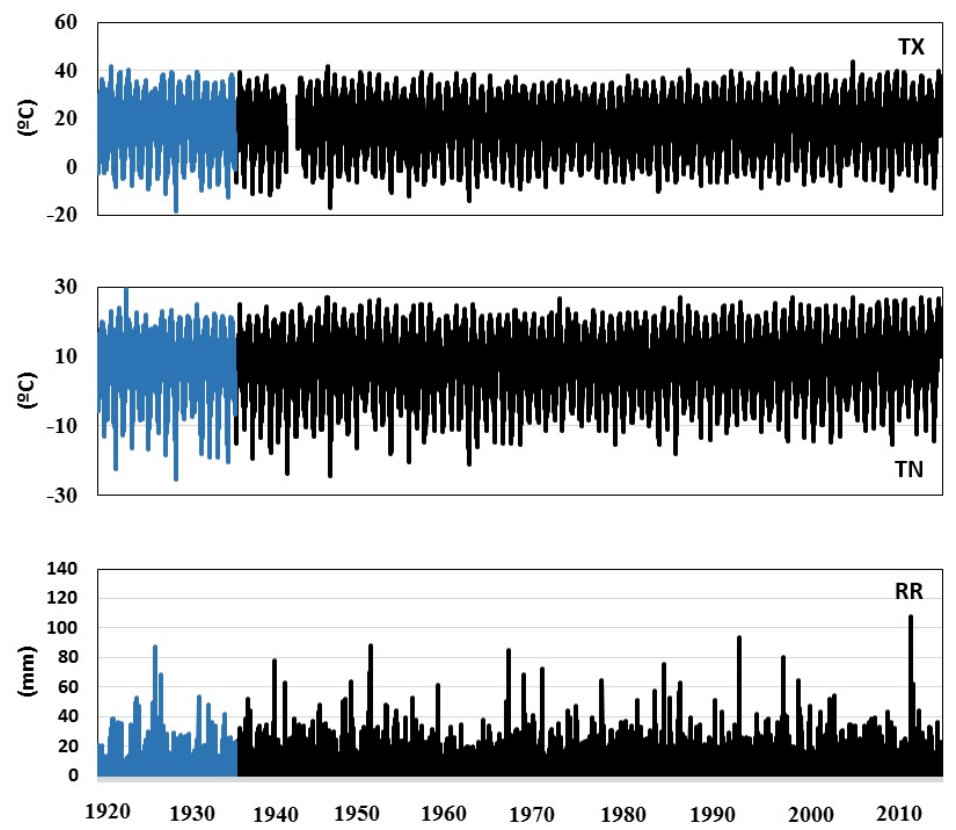

Figure 11: Evolution of daily maximum (TX) minimum (TN) temperature and precipitation (RR) at Belgrade station (Republic of Serbia) for the period 1920-2017. The period 1920-1935 was rescued in this study (blue line) meanwhile the period 1936-2017 was obtained from ECA\&D Dataset (dark line). 
Earth Syst. Sci. Data Discuss., https://doi.org/10.5194/essd-2019-6

Manuscript under review for journal Earth Syst. Sci. Data

Discussion started: 21 January 2019

(c) Author(s) 2019. CC BY 4.0 License.
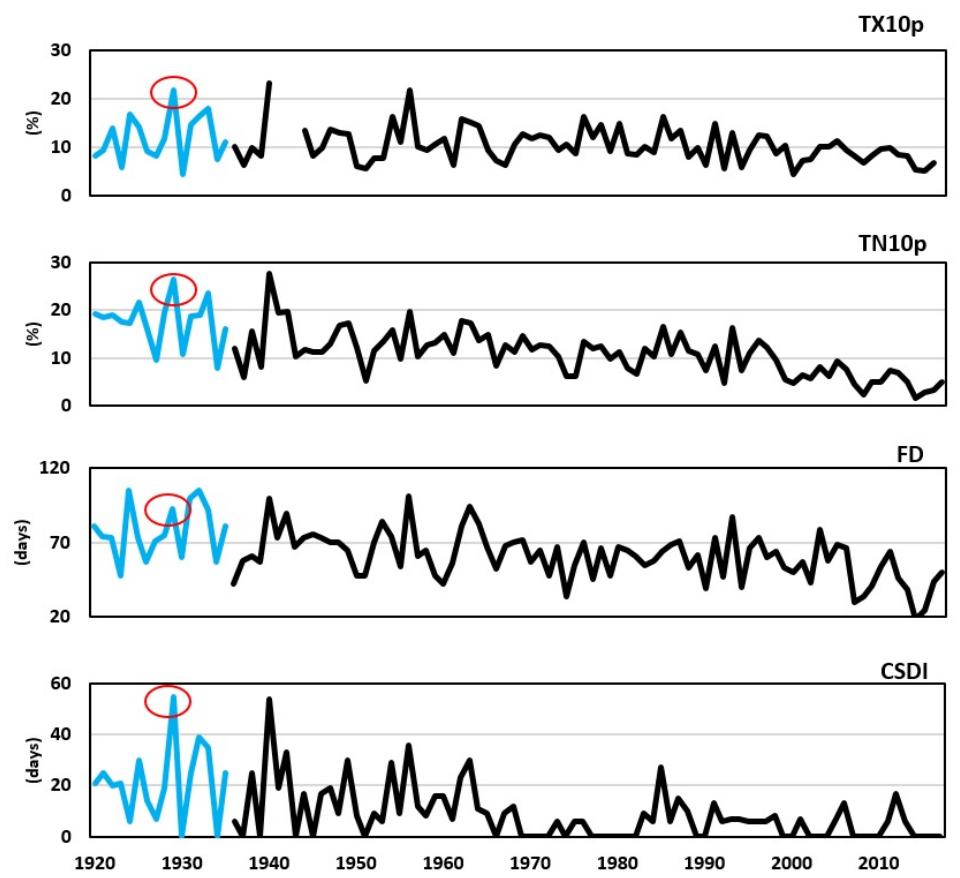

Figure 12: Time series of TX10p, TN10p, FD and CSDI extreme indices at Belgrade station (Republic of Serbia) for the period 1920-2017. The period 1920-1935 was rescued in this study (blue line) meanwhile the period 1936-2017 was obtained from ECA\&D Dataset (dark line). Red circle shows a climatic extreme (cold year) identified in 1929. 
Earth Syst. Sci. Data Discuss., https://doi.org/10.5194/essd-2019-6

Manuscript under review for journal Earth Syst. Sci. Data

Discussion started: 21 January 2019

(c) Author(s) 2019. CC BY 4.0 License.
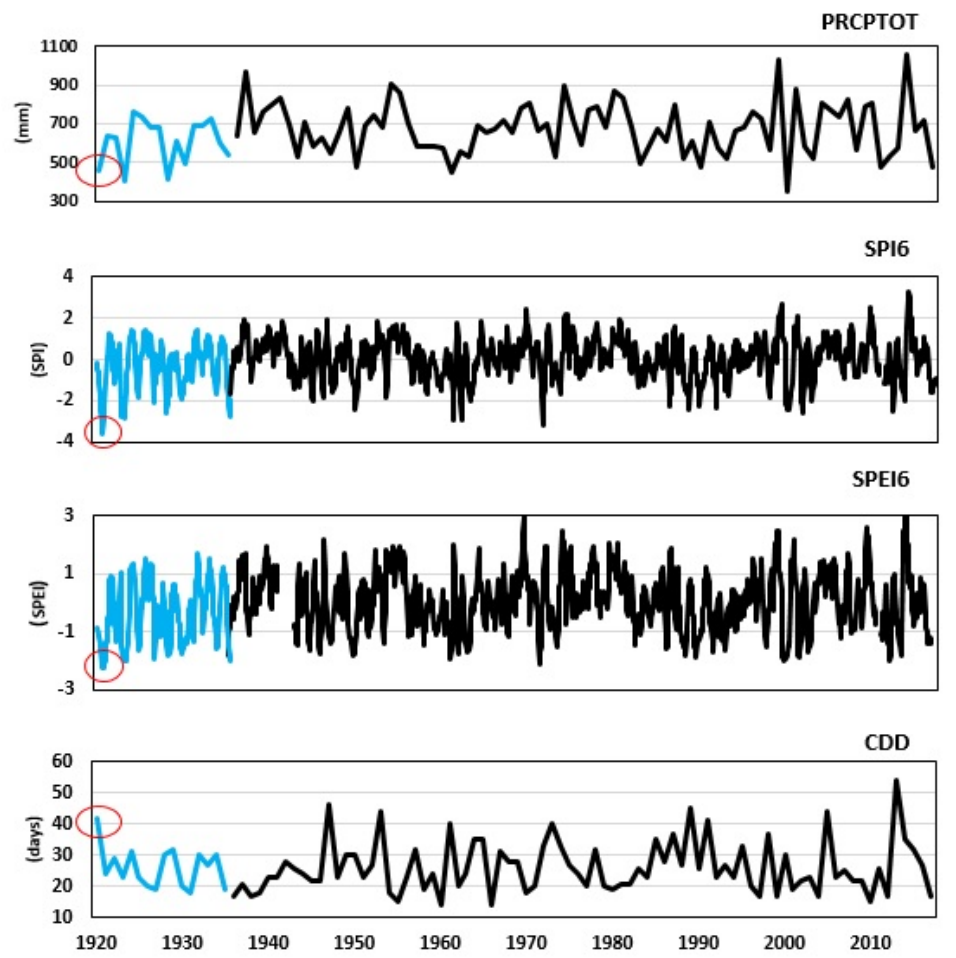

Figure 13: Time series of PRCPTOT, SPI 6-month, SPEI 6-month and CDD extreme indices at Belgrade station (Republic of Serbia) for the period 1920-2017. The period 1920-1935 was rescued in this study (blue line) meanwhile the period 1936-2017 was obtained from ECA\&D Dataset (dark line). Red circle shows a climatic extreme (dry years) identified in 1920-1921. 
Earth Syst. Sci. Data Discuss., https://doi.org/10.5194/essd-2019-6

Manuscript under review for journal Earth Syst. Sci. Data

Discussion started: 21 January 2019

(C) Author(s) 2019. CC BY 4.0 License.

(c) (i)

570

571 Table 1: Documental data sources used for data rescue purposes.

\begin{tabular}{|c|c|c|}
\hline \multirow{4}{*}{ Region } & Documental Source & Period \\
\hline \multirow{4}{*}{ Central Europe } & $\begin{array}{c}\text { Rocenka povetrnostnich posoro vani site statniho ustavu } \\
\text { meteorologickeho. }\end{array}$ & $1916-1946$ \\
\cline { 2 - 3 } & $\begin{array}{c}\text { Rocenka povetrnostnich pozorovani meteorologickeho stanie } \\
\text { Republiky Ceskoslovenshe. }\end{array}$ & $1948-1968$ \\
\cline { 2 - 3 } & $\begin{array}{c}\text { Rocenka povetrnostnych pozorovani observtoria na Lomnickom Stite. } \\
\text { Balkans Region }\end{array}$ & $1940-1974$ \\
\cline { 2 - 3 } & Izvestaj meteoroloske opservatorije u Beogradu. & $1920-1945$ \\
\cline { 2 - 3 } & Resultati osmatranija u Beogradu. & $1946-1950$ \\
\cline { 2 - 3 } & $\begin{array}{c}\text { Scans from original log-books provided by the Croatian } \\
\text { Meteorological and Hydrological Service (DHMZ) }\end{array}$ & $1949-2012$ \\
\hline
\end{tabular}

572

573 
Earth Syst. Sci. Data Discuss., https://doi.org/10.5194/essd-2019-6

Manuscript under review for journal Earth Syst. Sci. Data

Discussion started: 21 January 2019

(c) Author(s) 2019. CC BY 4.0 License.

574 Table 2: Rescued data included in the INDECIS-Raw-Dataset. Specific metadata such as country, WMO 575 code, station name, latitude, longitude, altitude and digitizing period are also shown. Digitized variables 576 are maximum (TX) and minimum (TN) temperature, rainfall (RR), snow depth (SD) and sunshine 577 duration (SS).

\begin{tabular}{|c|c|c|c|c|c|c|c|}
\hline Country & $\begin{array}{l}\text { WMO } \\
\text { code }\end{array}$ & $\begin{array}{l}\text { Station } \\
\text { Name }\end{array}$ & Lat. $\mathbf{N}$ & Lon. E & $\begin{array}{l}\text { Alt. } \\
\text { (m) }\end{array}$ & Variables & $\begin{array}{c}\text { Digitizing } \\
\text { period }\end{array}$ \\
\hline \multirow{11}{*}{$\begin{array}{c}\text { Czech } \\
\text { Republic }\end{array}$} & 11542 & $\begin{array}{c}\text { Ceske } \\
\text { Budejovice }\end{array}$ & $48^{\circ} 58^{\prime} 00^{\prime \prime}$ & $14^{\circ} 28^{\prime} 00^{\prime \prime}$ & 389 & $\mathrm{TX} / \mathrm{TN} / \mathrm{RR} / \mathrm{SD}$ & $1917-1938$ \\
\hline & 11748 & Prerov & $49^{\circ} 28^{\prime} 00^{\prime \prime}$ & $17^{\circ} 27^{\prime} 00^{\prime \prime}$ & 214 & $\mathrm{TX} / \mathrm{TN} / \mathrm{RR} / \mathrm{SD}$ & 1917-1952 \\
\hline & 11406 & Eger/Cheb & $50^{\circ} 05^{\prime} 00^{\prime \prime}$ & $12^{\circ} 24^{\prime} 00^{\prime \prime}$ & 483 & $\mathrm{TX} / \mathrm{TN} / \mathrm{RR} / \mathrm{SD}$ & 1919-1936 \\
\hline & 11763 & $\begin{array}{l}\text { Troppau/ } \\
\text { Opava }\end{array}$ & $49^{\circ} 56^{\prime} 00^{\prime}$ & $17^{\circ} 53^{\prime} 00^{\prime \prime}$ & 268 & TX/TN/RR/SD & $1917-1937$ \\
\hline & 11461 & $\begin{array}{c}\text { Teplitz- } \\
\text { Schnonau }\end{array}$ & $50^{\circ} 39^{\prime} 00^{\prime \prime}$ & $13^{\circ} 48^{\prime} 00^{\prime \prime}$ & 229 & TX/TN/RR/SD & 1917-1936 \\
\hline & 11446 & Plzen & $49^{\circ} 44^{\prime} 00^{\prime \prime}$ & $13^{\circ} 80^{\prime} 00^{\prime \prime}$ & 357 & TX/TN/RR/SD & 1948-1953 \\
\hline & 99999 & Turnov & $50^{\circ} 36^{\prime} 00^{\prime \prime}$ & $15^{\circ} 10^{\prime} 00^{\prime \prime}$ & 280 & $\mathrm{TX} / \mathrm{TN} / \mathrm{RR} / \mathrm{SD}$ & 1948-1951 \\
\hline & 11721 & Brno-Kvetna & $49^{\circ} 12^{\prime} 00^{\prime \prime}$ & $16^{\circ} 34^{\prime} 00^{\prime \prime}$ & 233 & TX/TN/RR/SD & 1948-1968 \\
\hline & 11735 & Praded & $50^{\circ} 05^{\prime} 00^{\prime \prime}$ & $17^{\circ} 14^{\prime} 00^{\prime \prime}$ & 1490 & $\mathrm{TX} / \mathrm{TN} / \mathrm{RR} / \mathrm{SD}$ & 1948-1957 \\
\hline & 11622 & Caslav-Filipor & $49^{\circ} 54^{\prime} 00^{\prime \prime}$ & $15^{\circ} 24^{\prime} 00^{\prime \prime}$ & 252 & TX/TN/RR/SD & $1946-1960$ \\
\hline & 99999 & Frycovice & $49^{\circ} 41^{\prime} 00^{\prime \prime}$ & $18^{\circ} 13^{\prime} 00^{\prime \prime}$ & 274 & $\mathrm{TX} / \mathrm{TN} / \mathrm{RR} / \mathrm{SD}$ & 1946-1953 \\
\hline \multirow{5}{*}{$\begin{array}{c}\text { Slovak } \\
\text { Republic }\end{array}$} & 99999 & $\begin{array}{l}\text { O.-Gyalla/ } \\
\text { Stara Dala }\end{array}$ & $47^{\circ} 53^{\prime} 00^{\prime \prime}$ & $18^{\circ} 12^{\prime} 00^{\prime \prime}$ & 120 & TX/TN/RR/SD & 1919-1937 \\
\hline & 99999 & St. Smokovec & $49^{\circ} 08^{\prime} 00^{\prime \prime}$ & $20^{\circ} 13^{\prime} 00^{\prime \prime}$ & 1018 & TX/TN/RR/SD & 1921-1937 \\
\hline & 11814 & $\begin{array}{c}\text { Bratislava- } \\
\text { Trnavaka } \\
\end{array}$ & $48^{\circ} 10^{\prime} 00^{\prime \prime}$ & $17^{\circ} 08^{\prime} 00^{\prime \prime}$ & 139 & TX/TN/RR/SD & 1946-1968 \\
\hline & 11931 & Skalnate Pleso & $49^{\circ} 12^{\prime} 00^{\prime \prime}$ & $20^{\circ} 55^{\prime} 00^{\prime \prime}$ & 1778 & TX/TN/RR/SD & $1946-1960$ \\
\hline & 11968 & Kosice & $48^{\circ} 42^{\prime} 00^{\prime \prime}$ & $21^{\circ} 16^{\prime} 00^{\prime \prime}$ & 206 & $\mathrm{TX} / \mathrm{TN} / \mathrm{RR} / \mathrm{SD}$ & 1946-1950 \\
\hline \multirow{3}{*}{$\begin{array}{l}\text { Republic of } \\
\text { Serbia }\end{array}$} & 13274 & Belgrade & $44^{\circ} 48^{\prime} 00^{\prime \prime}$ & $20^{\circ} 28^{\prime} 00^{\prime \prime}$ & 132 & $\mathrm{TX} / \mathrm{TN} / \mathrm{RR}$ & 1920-1935 \\
\hline & 13367 & Zlatibor & $43^{\circ} 44^{\prime} 00^{\prime \prime}$ & $19^{\circ} 43^{\prime} 00^{\prime \prime}$ & 1028 & $\mathrm{TX} / \mathrm{TN} / \mathrm{RR} / \mathrm{SD} / \mathrm{SS}$ & 1992-2012 \\
\hline & 13489 & Vranje & $42^{\circ} 33^{\prime} 00^{\prime \prime}$ & $21^{\circ} 55^{\prime} 00^{\prime \prime}$ & 432 & $\mathrm{TX} / \mathrm{TN} / \mathrm{RR} / \mathrm{SD} / \mathrm{SS}$ & 1999-2012 \\
\hline \multirow{2}{*}{$\begin{array}{c}\text { Bosnia \& } \\
\text { Herzegovina }\end{array}$} & 13353 & Sarajevo & $43^{\circ} 52^{\prime} 00^{\prime \prime}$ & $18^{\circ} 26^{\prime} 00^{\prime \prime}$ & 630 & SD/SS & $1949-1960$ \\
\hline & 13352 & Bjelasnica & $43^{\circ} 43^{\prime} 00^{\prime \prime}$ & $18^{\circ} 16^{\prime} 00^{\prime \prime}$ & 2067 & $\mathrm{SD} / \mathrm{SS}$ & 1953-1960 \\
\hline Montenegro & 13462 & $\begin{array}{l}\text { Titograd/ } \\
\text { Podgorica }\end{array}$ & $42^{\circ} 26^{\prime} 00^{\prime \prime}$ & $19^{\circ} 17^{\prime} 00^{\prime \prime}$ & 52 & $\mathrm{TX} / \mathrm{TN} / \mathrm{RR} / \mathrm{SD} / \mathrm{SS}$ & 1949-1984 \\
\hline \multirow{2}{*}{$\begin{array}{l}\text { Republic of } \\
\text { Macedonia }\end{array}$} & 13491 & Skopje & $41^{\circ} 59^{\prime} 00^{\prime \prime}$ & $21^{\circ} 28^{\prime} 00^{\prime \prime}$ & 240 & TX/TN/RR/SD/SS & 1949-1972 \\
\hline & 13586 & $\begin{array}{c}\text { Skopje } \\
\text { (Petrovac) }\end{array}$ & $41^{\circ} 58^{\prime} 00^{\prime \prime}$ & $21^{\circ} 39^{\prime} 00^{\prime \prime}$ & 238 & $\mathrm{RR} / \mathrm{SD} / \mathrm{SS}$ & 1974-1984 \\
\hline Croatia & 5080 & Brodanci & $45^{\circ} 32^{\prime} 33^{\prime \prime}$ & $18^{\circ} 27^{\prime} 26^{\prime \prime}$ & 92 & RR/SD & $1930-1990$ \\
\hline
\end{tabular}


Earth Syst. Sci. Data Discuss., https://doi.org/10.5194/essd-2019-6

Manuscript under review for journal Earth Syst. Sci. Data

Discussion started: 21 January 2019

(c) Author(s) 2019. CC BY 4.0 License.

\section{(c) (i)}

584 Table 3: Metadata collection by using specific templates

\begin{tabular}{|c|c|c|c|}
\hline \multicolumn{4}{|c|}{ Metadata on data sources } \\
\hline \multicolumn{4}{|c|}{ Title of the source: Meteoroloski godisnjak. I } \\
\hline \multicolumn{4}{|c|}{ Period covered by the source: $1949-1978$} \\
\hline \multicolumn{4}{|c|}{$\begin{array}{c}\text { Available at: CDMP-NOAA: } \\
\text { http://library.noaa.gov/Collections/Digital-Documents/Foreign-Climate-Data-Home }\end{array}$} \\
\hline \multicolumn{4}{|c|}{ Variables included: Maximum and minimum temperature, rainfall and snow depth } \\
\hline \multicolumn{4}{|c|}{ Station Identifiers } \\
\hline Station Name: & Ceske Budejovice & WMO code: & 11542 \\
\hline Country: & Czech Republic & Altitude (m): & 389 \\
\hline Latitude: & $48^{\circ} 58^{\prime} 00^{\prime \prime}$ & Longitude: & $14^{\circ} 28^{\prime} 00^{\prime \prime}$ \\
\hline \multicolumn{4}{|c|}{ Variables Metadata } \\
\hline Variable & Units & Period & Observing times \\
\hline Max. Temperature (TX) & $\left({ }^{\circ} \mathrm{C}\right)$ & $1917-1938$ & Daily \\
\hline Min. Temperature (TN) & $\left({ }^{\circ} \mathrm{C}\right)$ & $1917-1938$ & Daily \\
\hline Rainfall (RR) & $(\mathrm{mm})$ & 1917-1938 & $7 \mathrm{am}$ \\
\hline Snow depth (SD) & $(\mathrm{cm})$ & $1917-1938$ & 7am \\
\hline \multicolumn{4}{|c|}{ Special Codes } \\
\hline Variable & Code & \multicolumn{2}{|c|}{ Description } \\
\hline TX/TN/RR/SD & $-99,9$ & \multicolumn{2}{|c|}{ Missing value } \\
\hline Rainfall & -3 & \multicolumn{2}{|c|}{ Rainfall $<0.1 \mathrm{~mm}$} \\
\hline Rainfall & -4 & \multicolumn{2}{|c|}{ Cumulative precipitation } \\
\hline Snow depth & 0,1 & \multicolumn{2}{|c|}{ Snow traces on the soil } \\
\hline \multicolumn{4}{|c|}{ Missing values and/or periods } \\
\hline \multicolumn{2}{|c|}{ Dates/Periods } & \multicolumn{2}{|c|}{ Incident } \\
\hline \multicolumn{2}{|c|}{ from $01 / 01 / 1919$ to $31 / 07 / 1919$} & \multicolumn{2}{|c|}{ No data } \\
\hline \multicolumn{2}{|c|}{ from $16 / 02 / 1921$ to $31 / 05 / 1921$} & \multicolumn{2}{|c|}{ Hard to read } \\
\hline \multicolumn{2}{|c|}{ from $25 / 03 / 1928$ to $31 / 03 / 1928$} & \multicolumn{2}{|c|}{ Hard to read } \\
\hline \multicolumn{2}{|c|}{ from $01 / 02 / 1931$ to $31 / 03 / 1931$} & \multicolumn{2}{|c|}{ No data } \\
\hline \multicolumn{4}{|c|}{ Station Metadata (if available) } \\
\hline \multicolumn{2}{|c|}{ Period of the incidence } & \multicolumn{2}{|c|}{ Type of incidence } \\
\hline \multicolumn{2}{|c|}{ December 1929} & \multicolumn{2}{|c|}{ Instrument changes: Thermometer } \\
\hline
\end{tabular}


Earth Syst. Sci. Data Discuss., https://doi.org/10.5194/essd-2019-6

Manuscript under review for journal Earth Syst. Sci. Data

Discussion started: 21 January 2019

(c) Author(s) 2019. CC BY 4.0 License.

(c) (1)

587 Table 4: Summary of number of rescued stations and total amount of digitized values for each country 588 and period. Variables are maximum (TX) and minimum (TN) temperature, rainfall (RR), snow depth 589 (SD) and sunshine duration (SS).

\begin{tabular}{|c|c|c|c|c|c|}
\hline Country & № stations & Variables & Period & Total digitized & $\%$ \\
\hline Czech Republic & 11 & TX/TN/RR/SD & $1917-1968$ & 245935 & 40,3 \\
\hline $\begin{array}{c}\text { Slovak } \\
\text { Republic }\end{array}$ & 5 & TX/TN/RR/SD & $1919-1968$ & 110873 & 18,2 \\
\hline $\begin{array}{c}\text { Republic of } \\
\text { Serbia }\end{array}$ & 4 & TX/TN/RR/SD/SS & $1920-2012$ & 85343 & 14,0 \\
\hline $\begin{array}{c}\text { Bosnia \& } \\
\text { Herzegovina }\end{array}$ & 1 & TX/TN/RR/SD/SS & $1949-1960$ & 8642 & 1,4 \\
\hline Montenegro & 1 & TX/TN/RR/SD/SS & $1949-1984$ & 64816 & 10,6 \\
\hline $\begin{array}{c}\text { Republic of } \\
\text { Macedonia }\end{array}$ & 2 & TX/TN/RR/SD/SS & $1949-1984$ & 51836 & 8,5 \\
\hline Croatia & 1 & RR/SD & $1930-1990$ & 42709 & 7,0 \\
\hline
\end{tabular}

